\title{
Influence of Atmospheric Plasma Spray Parameters (APS) on the Mechanical Properties of Ni-Al Coatings on Aluminum Alloy Substrate
}

\author{
Miriam Lorenzo-Bañuelos ${ }^{1, * \mathbb{C}}$, Andrés Díaz ${ }^{1} \mathbb{D}$, David Rodríguez ${ }^{2}$, Isidoro I. Cuesta ${ }^{1} \mathbb{D}$, Adrian Fernández ${ }^{2}$ and \\ Jesus M. Alegre ${ }^{1}$ (D) \\ 1 Structural Integrity Research Group, Universidad de Burgos, Avenida Cantabria s/n, 09006 Burgos, Spain; \\ adportugal@ubu.es (A.D.); iicuesta@ubu.es (I.I.C.); jalegre@ubu.es (J.M.A.) \\ 2 Fundación Centro Tecnológico de Miranda de Ebro (CTME), Calle Montañana-Parcelas R 60-R 61, Polígono. \\ Industrial de Bayas, 09200 Miranda de Ebro, Burgos, Spain; davidrodriguez@ctme.es (D.R.); \\ adrianfernandez@ctme.es (A.F.) \\ * Correspondence: mlbanuelos@ubu.es
}

check for

updates

Citation: Lorenzo-Bañuelos, M.; Díaz, A.; Rodríguez, D.; Cuesta, I.I.; Fernández, A.; Alegre, J.M. Influence of Atmospheric Plasma Spray Parameters (APS) on the Mechanical Properties of Ni-Al Coatings on Aluminum Alloy Substrate. Metals 2021, 11, 612. https://doi.org/ $10.3390 /$ met11040612

Academic Editor: Qingsong Wei

Received: 7 March 2021

Accepted: 6 April 2021

Published: 9 April 2021

Publisher's Note: MDPI stays neutral with regard to jurisdictional claims in published maps and institutional affiliations.

Copyright: (c) 2021 by the authors. Licensee MDPI, Basel, Switzerland. This article is an open access article distributed under the terms and conditions of the Creative Commons Attribution (CC BY) license (https:// creativecommons.org/licenses/by/ $4.0 /)$.

\begin{abstract}
Thermal spray is one of the most widely used coating techniques to improve wear, surface fatigue or corrosion properties. In the atmospheric plasma spray (APS) process, a powdered material is melted by hydrogen and argon combustion and is propelled at high speed onto the target substrate. The high impact energy of the particles produces a dense and resistant coating layer. Mechanical and surface properties of the obtained coating depend on various spraying parameters, such as gas flow, traverse speed and spraying distance, among others. In this research, the influence of these manufacturing parameters on the thickness, hardness and resistance of the coating obtained from a Ni-Al alloy sprayed onto an aluminum alloy substrate was studied. In order to analyze the effect of these parameters on the coating properties, an extensive experimental program was carried out. A metallographic analysis, hardness and strength measurements were carried out using the small punch test to locally study the mechanical properties of the coating surface. The design of experiments and the response surface methodology facilitate the assessment of the optimal set of spraying parameters.
\end{abstract}

Keywords: thermal spray; APS; small punch test (SPT); Ni-Al coating; aluminum alloy

\section{Introduction}

Components manufactured in different industries require an optimum strength-toweight ratio. Some properties, such as fatigue, creep, creep-fatigue, high temperature, corrosion and wear resistance, must also be considered depending on their functionality. For instance, landing gear dampers absorb and dissipate landing impact energy and reduce stresses on the fuselage. For this reason, many of the components of the landing gear have usually been plated with hard chrome [1-3]. However, environmental regulations demand the replacement of these hexavalent chromium components due to their harmful effects on health [4]. In this context, coatings obtained by thermal spraying are a feasible alternative because, in addition to environmental issues, they improve mechanical performance in comparison with conventional hard chrome coatings, both for wear and corrosion behavior $[3,5,6]$. Turbine blades in the aeronautical field are also critical because they are susceptible to fatigue and thermal creep failures [7-9]. Moreover, due to the temperatureenhanced oxidation [10], coatings are commonly designed as a thermal barrier coating (TBC) for components that are in contact with hot gases [11-13]. A type of TBC commonly used in aeronautics and obtained by thermal spraying is the Ni-Al coating. It is used to protect components subjected to high temperatures and is mainly characterized by very good adhesion to the substrate [14]. In this case, a top coat ceramic layer, typically $\mathrm{ZrO}_{2}$ 
stabilized with $8 \% \mathrm{Y}_{2} \mathrm{O}_{3}[15,16]$, which acts as a thermal insulator of the component [17], is projected onto the Ni-Al metallic layer, i.e., the bond coat. On the other hand, aluminum substrates are used in applications where the weight must be minimum; however, the low hardness and tribological properties need to be enhanced by different coating techniques.

High-velocity oxy-fuel (HVOF) and atmospheric plasma spray (APS) are among the most widely used thermal spray techniques [18]. The main difference between HVOF and APS thermal spray techniques is the speed at which the particles are projected and the materials that can be projected. The acceleration of the molten or softened particles to be projected on the substrate depends on the gases present in that atmosphere. At the same time that the heat transfer process takes place, pressurized gas streams are produced in the working atmosphere. The pressure can be obtained with suitable geometries of nozzles in the spray guns or by means of peripheral devices. In the case of HVOF particles projected at high speed, the coatings have better adhesion and mechanical properties. Carbide coatings with maximum hardness and wear resistance are obtained. However, the APS technique can be applied to a greater variety of materials to be protected with good quality. The fields of application for both techniques in metallic and ceramic coatings are the aeronautical, oil and gas, textile and steel sectors.

In particular, APS is a coating technique whereby a powdered material is melted in a hydrogen and argon combustion process and then propelled toward the substrate at high speed. The high impact energy of the particles produces a dense and resistant coating layer $[12,19,20]$. Plasma in contact with powder particles in the heating region reaches temperatures between 6000 and $15,000{ }^{\circ} \mathrm{C}$ [21]. A gas mixture of hydrogen and argon is overheated by an electric arc to produce plasma. Simultaneously, the powder is introduced radially using an inert carrier gas and is accelerated toward the substrate by the plasma stream. Therefore, refrigeration is required to keep the substrate between 95 and $205^{\circ} \mathrm{C}$ [21].

\subsection{APS Process Parameters}

Typical parameters influencing the APS process include the plasma gas composition, the geometry of the electrodes, the spraying distance, the atmosphere used, the transverse speed of the torch, the substrate temperature and the powder size and quality [22-24]. Generally, the plasma gas is composed of Ar or mixtures of $\mathrm{Ar}+\mathrm{H}_{2}, \mathrm{Ar}+\mathrm{He}$ and $\mathrm{Ar}+\mathrm{N}_{2}$, sometimes $\mathrm{N}_{2}$ and a mixture of $\mathrm{N}_{2}+\mathrm{H}_{2}$. For industrial applications, typical Ar flow rates in plasma torches, such as F4, range between 40 and 50 slpm, and can reach 80 slpm in some facilities. Each gas has its own role in the formation of the plasma jet [25]: Ar stabilizes the arc within the nozzle, whereas $\mathrm{N}_{2}$ or $\mathrm{H}_{2}$ improve heat transfer to the particles, due to their high thermal conductivity. The plasma composition also has an influence on plasma jet velocity and enthalpy [26]. The plasma torch temperature is approximately $13,727^{\circ} \mathrm{C}$ [27], reaching particle velocities at the nozzle outlet from 20 to $500 \mathrm{~m} / \mathrm{s}$, depending on the particle size [28]. For APS, the spraying distance from the torch to the substrate varies from 60 to $150 \mathrm{~mm}$, whereas the atmosphere is usually air. Moreover, the temperature of the substrate is an important parameter for ceramic coatings that are sprayed on metals due to the likely generation of residual stresses [29-32]. In alumina coatings, it has been demonstrated that adhesion is best when the substrate temperature is between 300 and $500{ }^{\circ} \mathrm{C}[33]$.

\subsection{Testing of Coatings}

Gradients of physical and mechanical properties between the substrate and the coating might produce failures, e.g., crack initiation and propagation, or reduction of corrosion and creep resistance [34-36]. It must be noted that thermal stresses are generated during cooling after fabrication [37] and that cracking within coatings can be caused also by thermal cycles in the absence of mechanical loading [38]; in addition, coating oxidation must be taken into account $[4,10,39,40]$. Failures of thermal spray coatings might be classified according to the operating mechanism in: abrasion, delamination, bulk failure and spalling [41]. 
Mechanical characterization of coatings has traditionally focused on the measurement of adhesive resistance between layers [42]. Some examples of common techniques are the tensile adhesion test, double cantilever beam test, scratch test or laser shock adhesion test (LASAT) [43]. Kang et al. [44] used Acoustic Emission technology to study delamination failures. In addition, due to the increasing use of thermal spray coatings, specific standards have emerged to evaluate their adhesion properties, such as the ISO 14916: 2017 [45] or the ISO 27307:2015 [46] that standardize the tensile adhesive test and the transverse scratch test, respectively, or the ISO 19207:2016 [47], which considers the classification of adhesive strength by indentation. In thermal spraying of coatings, the most used test is ASTM C633 [48]. It is used to determine the adhesion or cohesion strength of thermal spray when subjected to tension perpendicular to the surface. To do this, a cylinder of the same metal that would be used as the coating substrate in actual use is sprayed. The cylinder length of this substrate shall not be less than $37.5 \mathrm{~mm}$, with parallel surfaces between 23 and $25 \mathrm{~mm}$ in diameter, with one end threaded to fix the load test tool and the other flat end for the application of the sprayed coating. Subsequently, a similar test tool, but without a coating, is glued to the surface of the coating with a suitable adhesive bonding agent. The adhesive bonding agent must be at least as strong as the required minimum adhesion strength or cohesion of the coating.

Adhesive fracture can also be determined using indentation results on the interface of layers [49]. Testing coating samples separated from the substrate by machining is also possible [50]. Some authors have studied the fracture toughness of plasma-sprayed thin specimens using a double-torsion test method [51] or a three-point bending test [52]. Nordhorn et al. [53] combined the three-point bending test on APS coatings with a probabilistic and FE-integrated approach. In comparison to the extensive research on adhesive properties, little research analyses the plastic behavior of thermally sprayed coating; macroindentation [54] and nanoindentation [55] tests, in combination with numerical modeling, are useful techniques to shed light on the ductile behavior and fracture micro-mechanisms of coatings. When a thin substrate and a biaxial stress state must be characterized, the small punch test (SPT) is proposed here as a feasible alternative for the failure analysis of coating-substrate systems.

\subsection{SPT on Coatings}

As an application example, SPT methodology has been used to mimic the expansion of stents inserted into arteries and, to this purpose, to study the failure of polymer-coated stents [56]. Chen et al. [57] studied the behavior of thermally sprayed CoNiCrAlY coatings using the vacuum plasma method. Tests were carried on at high temperature and constant load, i.e., small punch creep test. They showed the important role of unmelted particles on initial cracking during the SP creep test. These authors also studied the HVOF method in CoNiCrAlY coating using the SP creep test [58], concluding that oxide particles originated during HVOF spray promote early failures. Other authors $[59,60]$ have used SPT on thermally sprayed coatings to obtain the ductile-to-brittle transition temperature (DBTT). A ductile-to-brittle transition shift is also observed for environmental effects in coated materials, as shown by Nambu et al. [61], who studied hydrogen embrittlement of niobium coated with palladium using in situ SPT under hydrogen permeation. Displacementcontrolled SP tests have been conducted by Kameda et al. [62,63] in CoCrAlY coatings over a wide range of temperatures $\left(22-950^{\circ} \mathrm{C}\right)$. These authors analyze the behavior of each coating region by machining off the outer layers so the specimen surface corresponds to the examined layer where crack initiation is expected to occur.

The small punch test has also been proposed as an adhesion test, especially for polymer-coated metals, because some adhesion failures have been observed in medical applications due to the mechanical expansion [56,64]. Eskner [65] gives a comprehensive overview of the estimation of mechanical properties of different coatings (NiAl, NiCrAlY, $\mathrm{NiCoCrAlY}$ ) on a Ni-base superalloy using the SPT for the application on gas turbines. 
In the present paper, the influence of the variation in APS parameters to obtain a Ni-Al metallic coating on an aluminum alloy substrate was studied. The relationship between the most significant process parameters and the mechanical properties of the coating-substrate system has been evaluated using the small punch test. In turn, the relationship between these APS parameters and the thickness, hardness and roughness of the obtained coating was assessed.

\section{Materials and Methods}

\subsection{Materials}

The substrate material that was considered is an aluminum alloy AW-5754-H111. This 5000 series aluminum alloy is characterized by a high magnesium content (2.6 to 3.6 weight \%). On the other hand, to obtain the desired coating by means of the APS technique, NiAl powder from Metco 450NS was used. This powder is widely employed in aeronautics to obtain, by thermal spray, metallic NiAl coatings on components that require an improvement in certain properties such as wear, high-temperature and corrosion resistance [66,67].

\subsection{Methodology}

Table 1 shows the combination of parameters considered for each sprayed sample. In total, 15 projected areas were obtained under different conditions, varying the spraying distance between 130 and $150 \mathrm{~mm}$, the spraying speed between 1000 and $1400 \mathrm{~mm} / \mathrm{s}$, the argon flow rate between 50 and 60 slpm and the hydrogen flow rate between 9 and 10 slpm. It must be noted that the spraying speed refers to the linear torch velocity and should not be confused with the powder particles' velocity. Even though both the argon and hydrogen flow rates are varied, only three gas combinations are defined $\left(\mathrm{Ar}-\mathrm{H}_{2}: 50-10,55-9.5\right.$ and 60-9 slpm); therefore, the gas ratio influence is addressed, from now onward, through the argon flow rate variable.

Table 1. Parameter combinations for Ni-Al spraying on an aluminum substrate by APS.

\begin{tabular}{|c|c|c|c|c|}
\hline $\begin{array}{c}\text { Combination } \\
\#\end{array}$ & $\begin{array}{c}\text { Spraying } \\
\text { Distance } \\
(\mathrm{mm})\end{array}$ & $\begin{array}{c}\text { Argon } \\
\text { Flow Rate } \\
\text { (slpm) }\end{array}$ & $\begin{array}{c}\mathrm{H}_{2} \\
\text { Flow Rate } \\
(\mathrm{slpm})\end{array}$ & $\begin{array}{c}\text { Spraying Speed } \\
(\mathrm{mm} / \mathrm{s})\end{array}$ \\
\hline 1 & 130 & 50 & 10 & 1000 \\
\hline 2 & 150 & 50 & 10 & 1000 \\
\hline 3 & 130 & 60 & 9 & 1000 \\
\hline 4 & 150 & 60 & 9 & 1000 \\
\hline 5 & 130 & 50 & 10 & 1400 \\
\hline 6 & 150 & 50 & 10 & 1400 \\
\hline 7 & 130 & 60 & 9 & 1400 \\
\hline 8 & 150 & 60 & 9 & 1400 \\
\hline 9 & 130 & 55 & 9.5 & 1200 \\
\hline 10 & 150 & 55 & 9.5 & 1200 \\
\hline 11 & 140 & 50 & 10 & 1200 \\
\hline 12 & 140 & 60 & 9 & 1200 \\
\hline 13 & 140 & 55 & 9.5 & 1000 \\
\hline 14 & 140 & 55 & 9.5 & 1400 \\
\hline 15 & 140 & 55 & 9.5 & 1200 \\
\hline
\end{tabular}

Ni-Al powder (Metco 450NS) was sprayed using surface one equipment with an F4 plasma torch (Oerlikon Metco, Switzerland) with a theoretical plasma temperature of $11,000{ }^{\circ} \mathrm{C}$ and nitrogen cooling. The aluminum substrate, before being sprayed with the coating particles, was shot-blasted using Norblast S-11 AUT equipment with an automatic shot blasting gun $(8 \mathrm{~mm})$ and a short distance of approximately $105 \mathrm{~mm}$. To obtain the final coating, ten layers were deposited on the aluminum substrate. Subsequently, from each of the 15 sprayed areas with the NiAl metal coating, i.e., one area for each parameter 
combination, $10 \times 10 \times 0.5 \mathrm{~mm}$ specimens were extracted by laser cutting. Small punch tests were carried out in these specimens. Three replicates of each defined experiment were tested for a total of 45 SPT tests, as described in Section 2.2.1. To carry out the small punch tests, a 430KN MTS-Criterion universal testing machine was used.

On the other hand, metallographic sample preparations were carried out for every combination of spraying parameters and Vickers HV0.3 surface microhardness was analyzed, according to ASTM E384-17, with 10 indentations and a minimum distance between indents of 2.5 times the indent diagonal. The coating thickness was measured from SEM images of the metallographic preparations. Ten thickness measurements were performed in 10 different fields of the SEM micrograph. Subsequently, a proctographic analysis of the samples was carried out by SEM after the Small Punch test. In addition, different surface roughness measurements were carried out, according to ISO 4287-1997, for all the 15 runs defined by combining APS parameters, using the Mitutoyo Surftest SJ210 roughness measuring instrument.

\subsubsection{Small Punch Test (SPT)}

This test, described in CEN [68], has also been used to determine fracture properties $[69,70]$. SPT is based on the punching of a thin specimen (0.5 $\mathrm{mm}$ thickness) until breaking, while its edges are clamped between lower and upper dies, by means of a highly rigid punch (Figure 1).

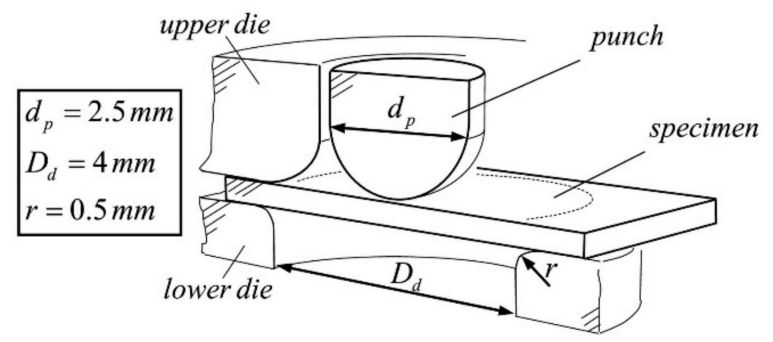

Figure 1. Small Punch testing scheme.

During the test, the load $\mathrm{P}$ applied to the punch is registered as well as the punch displacement, which corresponds to the specimen deflection in its centre, $\Delta(\mathrm{mm})$. From the SPT curves, the following values are extracted: maximum load, $\mathrm{P}_{\max }$; yield load, $\mathrm{P}_{\mathrm{y} /(\mathrm{t} / 10)}$; and the displacement corresponding to maximum load, $\Delta_{\mathrm{P}_{\max }}$ (Figure 2).

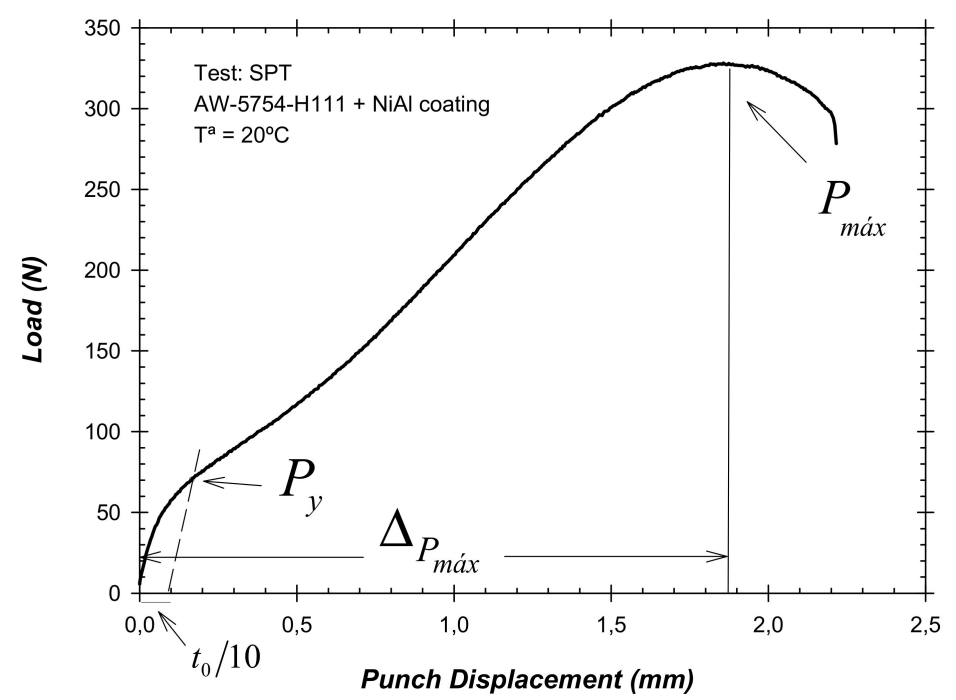

Figure 2. Typical load-displacement curve for the Small Punch Test. 


\subsubsection{Surface Roughness}

A study of the surface roughness produced by the APS coating process was carried out. Measurements have followed the ISO 4287-1997 Standard [71]. The following parameters were obtained to characterize the surface profile and thus the associated roughness:

- Amplitude field parameters: $R a, R q, R z, R p$ and $R v$. These parameters are related to the averaged profile ordinates ( $\mathrm{Ra}$ and $\mathrm{Rq})$ or to the peak/valley amplitudes $(\mathrm{Rz}, \mathrm{Rp}$, Rv).

- Peak/valley feature parameter: Rc This parameter represents the mean height of profile elements within the sampling length.

- $\quad$ Spacing feature parameter: RSm. It is determined by averaging the width of profile elements.

In the present work, the focus is put on the parameter Ra because it is by far the most common characterising magnitude in roughness evaluation. However, all values are given in Table 2. Ra is defined as the arithmetical mean deviation of the absolute ordinate values $Z(x)$ within the measured length l; this definition is expressed by Equation (1) and schematically depicted in Figure 3.

$$
R a=\frac{1}{l} \int_{0}^{l}|Z(x)| d x
$$

Table 2. Results of Small Punch tests, coating thickness measurement, microhardness and surface roughness values for each APS parameter combination, following the numbering sequence from Table 1.

\begin{tabular}{|c|c|c|c|c|c|c|c|c|c|c|c|c|}
\hline Run & $P_{y /(t / 10)}$ & $\begin{array}{c}P_{\max } \\
(\mathrm{N})\end{array}$ & $\begin{array}{l}\Delta_{P_{\max }} \\
(\mathrm{mm})\end{array}$ & $\begin{array}{c}\text { Coating } \\
\text { Thickness } \\
(\mu \mathrm{m})\end{array}$ & $\begin{array}{c}\text { Microhardness } \\
(0.3 \mathrm{HV})\end{array}$ & $\begin{array}{c}R a \\
(\mu \mathrm{m})\end{array}$ & $\begin{array}{c}R q \\
(\mu \mathrm{m})\end{array}$ & $\begin{array}{c}R z \\
(\mu \mathrm{m})\end{array}$ & $\begin{array}{c}R p \\
(\mu \mathrm{m})\end{array}$ & $\begin{array}{c}R v \\
(\mu \mathrm{m})\end{array}$ & $\begin{array}{c}R c \\
(\mu \mathrm{m})\end{array}$ & $\begin{array}{l}R S m \\
(\mu \mathrm{m})\end{array}$ \\
\hline 1 & 55.1 & 264.6 & 1.92 & $78 \pm 23$ & $142 \pm 4$ & 7.5 & 9.3 & 45.8 & 23.2 & 22.7 & 31.3 & 239.3 \\
\hline 2 & 58.6 & 253.3 & 1.87 & $112 \pm 12$ & $385 \pm 15$ & 4.8 & 6.1 & 32.9 & 16.2 & 16.8 & 18.5 & 137.1 \\
\hline 3 & 61.6 & 337.0 & 1.87 & $112 \pm 19$ & $169 \pm 46$ & 9.9 & 12.4 & 53.9 & 26.3 & 27.7 & 35.1 & 196.3 \\
\hline 4 & 56.0 & 272.6 & 1.94 & $143 \pm 24$ & $142 \pm 19$ & 13.8 & 16.8 & 71.3 & 33.4 & 37.9 & 53.5 & 265.3 \\
\hline 5 & 63.2 & 325.3 & 1.89 & $97 \pm 25$ & $162 \pm 26$ & 4.7 & 6.0 & 30.7 & 16.3 & 14.4 & 18.0 & 123.0 \\
\hline 6 & 54.0 & 288.9 & 1.91 & $87 \pm 28$ & $159 \pm 12$ & 9.6 & 12.1 & 55.0 & 27.0 & 28.0 & 35.3 & 240.9 \\
\hline 7 & 50.7 & 262.6 & 1.94 & $82 \pm 29$ & $167 \pm 19$ & 9.4 & 11.6 & 52.7 & 26.4 & 26.3 & 33.9 & 218.8 \\
\hline 8 & 53.1 & 250.9 & 1.89 & $164 \pm 35$ & $152 \pm 31$ & 12.0 & 14.5 & 61.7 & 32.0 & 29.7 & 44.4 & 287.2 \\
\hline 9 & 54.5 & 246.6 & 1.94 & $60 \pm 25$ & $95 \pm 16$ & 7.8 & 9.8 & 46.5 & 23.7 & 22.8 & 30.0 & 184.9 \\
\hline 10 & 52.9 & 269.2 & 1.91 & $248 \pm 22$ & $202 \pm 38$ & 10.8 & 13.2 & 58.3 & 29.5 & 28.9 & 39.3 & 229.0 \\
\hline 11 & 54.0 & 283.7 & 1.93 & $64 \pm 9$ & $164 \pm 42$ & 10.6 & 12.9 & 58.4 & 27.9 & 30.5 & 44.8 & 276.5 \\
\hline 12 & 54.6 & 263.5 & 1.92 & $191 \pm 55$ & $162 \pm 9$ & 9.1 & 11.0 & 49.1 & 23.5 & 25.6 & 32.3 & 206.8 \\
\hline 13 & 66.5 & 365.9 & 1.87 & $124 \pm 40$ & $138 \pm 32$ & 9.7 & 11.7 & 55.4 & 27.8 & 27.6 & 38.8 & 268.5 \\
\hline 14 & 57.1 & 276.2 & 1.91 & $165 \pm 31$ & $193 \pm 37$ & 11.3 & 13.7 & 59.4 & 29.8 & 29.6 & 44.4 & 287.2 \\
\hline 15 & 52.4 & 288.7 & 1.88 & $188 \pm 58$ & $150 \pm 22$ & 9.4 & 12.1 & 58.1 & 34.0 & 24.1 & 31.0 & 244.9 \\
\hline
\end{tabular}

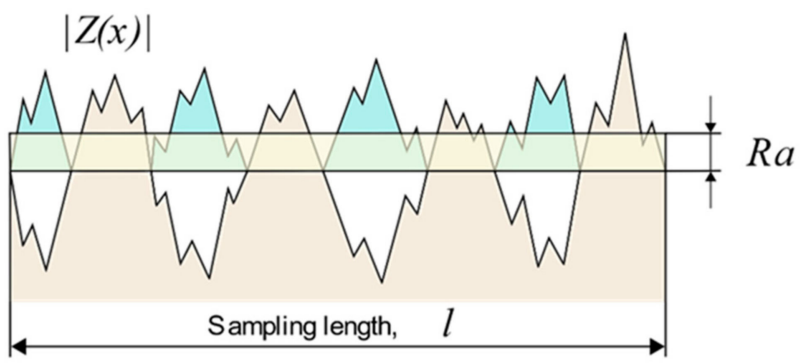

Figure 3. Scheme for the determination of the $R a$ roughness parameter. 


\section{Results}

SPT results are shown in Columns 2 to 4 in Table 2 for the corresponding parameter combination numbered in Column 1; following [68], the values $P_{y /(t / 10)}, P_{\max }$ and $\Delta_{P_{\max }}$ were determined. Measurements of coating thickness that were obtained by APS on the aluminum alloy substrate are included in Column 4. Additionally, microhardness results are shown in Column 5, whereas the surface roughness characteristic parameters are included in Columns 6 to 12.

\section{Discussion}

In order to facilitate the interpretation of results, three characterizing input variables were considered as the influential factors in the mechanical response and coating quality: spraying distance, argon flow rate and transverse spraying speed, following Table 1, and a response surface methodology (RSM) was followed to analyze results shown in Table 2. Input variables were codified to obtain a cubic design of experiments (DoE) in which these variables range between -1 and 1 , as shown in Figure 4. The DoE approach is usually followed to optimize process parameters for coatings [34,72-74]. More advanced regression techniques that are based on artificial neural networks have also been used by some authors to predict the influence of thermal spray parameters [75,76]. A codified value $x$ is determined from the dimensional magnitude $X$ following Equation (2):

$$
x=\frac{2(X-\tilde{X})}{X_{\text {sup }}-X_{\text {inf }}}
$$

where $\widetilde{X}, X_{\text {inf }}$ and $X_{\text {sup }}$ are the mean, inferior and superior values, respectively.

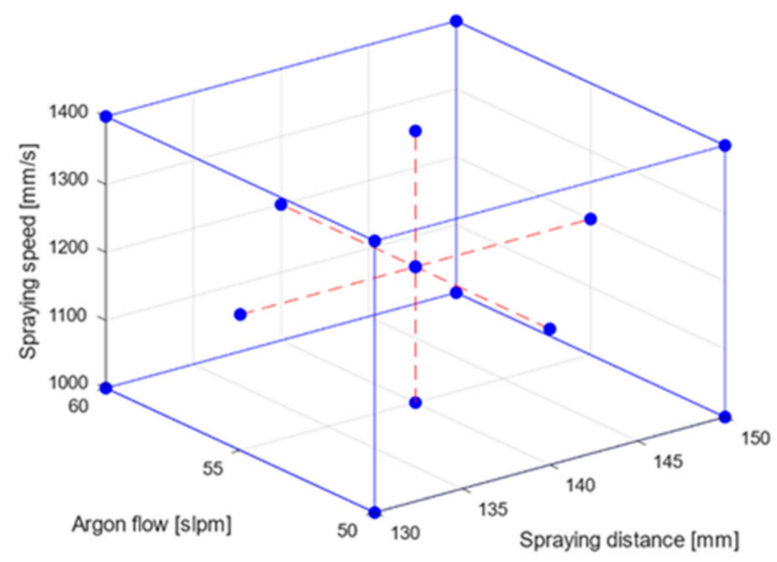

(a)

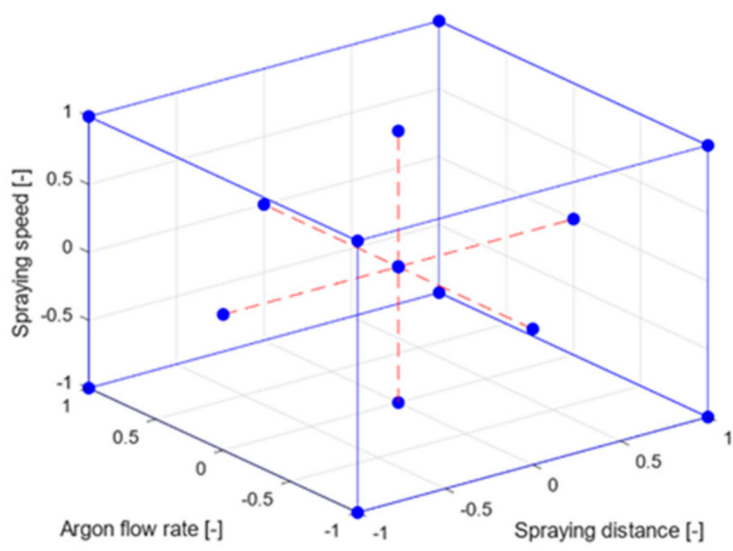

(b)

Figure 4. Central composite design for 3 factors with faced points and considering (a) real units $X$ or (b) codified units $x$.

For the output fitting, a quadratic surface response was considered with three variables: the spraying distance, $x_{1}$; the argon flow rate, $x_{2}$; and the spraying speed, $x_{3}$, all three codified, i.e., ranging between -1 and 1 . As shown in Equation (3), the surface response $f_{\text {out }}$ expression includes constant $\left(\beta_{0}\right)$, linear $\left(\beta_{1}, \beta_{2}, \beta_{3}\right)$, interaction $\left(\beta_{12}, \beta_{13}, \beta_{23}\right)$ and quadratic terms $\left(\beta_{11}, \beta_{22}, \beta_{33}\right)$.

$$
f_{\text {out }}\left(x_{1}, x_{2}, x_{3}\right)=\beta_{0}+\beta_{1} x_{1}+\beta_{2} x_{2}+\beta_{3} x_{3}+\beta_{12} x_{1} x_{2}+\beta_{13} x_{1} x_{3}+\beta_{23} x_{2} x_{3}+\beta_{11} x_{1}^{2}+\beta_{22} x_{2}^{2}+\beta_{33} x_{3}^{2}
$$

The surface response is fitted using the MathLab function "regstats" that performs the multilinear regression; the quadratic option including interaction terms was chosen. In the following subsections, four output experimental results are analyzed through this regression methodology: maximum load in $\mathrm{SPT}\left(\mathrm{P}_{\max }\right)$, the measured coating thickness, the 
microhardness value and the surface roughness $R a$. Generally, the fitted responses showed $\mathrm{R} 2$ regression coefficients between 0.65 and 0.75 . This moderate explained dependence was attributed to the usual scatter found in Small Punch testing and due to the nature of the Thermal Spray process in which homogeneous properties are hard to be found. Nevertheless, the influence of APS parameters was discussed by analyzing the fitted responses and the corresponding output contours.

\subsection{Maximum Load in SPT}

Table 3 shows the response surface coefficients for $P_{\max }$ as a function of the codified input variables. It can be seen that, in order to obtain higher values of $P_{\max }$, the most influential variable is the spraying speed. The higher the speed, the higher the $P_{\max }$ value. This observation can be explained by the fact that, at a higher spraying speed, less material is deposited for each pass of the gun, and a more compact and resistant coating is generated. In turn, this effect may be related to better adherence of the projected particles to the substrate so that coating spalling effects do not occur between each pass.

Table 3. Regression coefficients for the $\mathrm{P}_{\max }$ response considering $x_{1}, x_{2}, x_{3}$ (in codified units) and $f_{\text {out }}$ in $\mathrm{N}$ and percentage over the mean $\mathrm{P}_{\max }$ value.

\begin{tabular}{ccccccccccc}
\hline & $\beta_{0}$ & $\beta_{1}$ & $\beta_{2}$ & $\beta_{3}$ & $\beta_{12}$ & $\beta_{13}$ & $\beta_{23}$ & $\beta_{11}$ & $\beta_{22}$ & $\beta_{33}$ \\
\hline$(\mathrm{N})$ & 287.6 & -10.1 & -2.9 & -9.0 & -3.6 & 3.4 & -24.1 & -28.3 & -12.6 & 34.8 \\
$(\%)$ & 101.1 & -3.6 & -1.0 & -3.1 & -1.2 & 1.2 & -8.5 & -9.9 & -4.4 & 12.2 \\
\hline
\end{tabular}

On the other hand, short spraying distances produce a certain increase in the value of $P_{\max }$. This is attributed to the fact that, as the spraying distances get smaller, the projected particles generate compression stresses in the substrate, thus increasing its cracking resistance and so increasing the SPT maximum load. Regarding the effect of the gas mixture, it is the least significant variable of the three.

In addition, as can be observed in Figure 5, the combination of moderate argon flow rates (55 slpm) with medium-low spraying distances gives the higher $P_{\max }$ values.
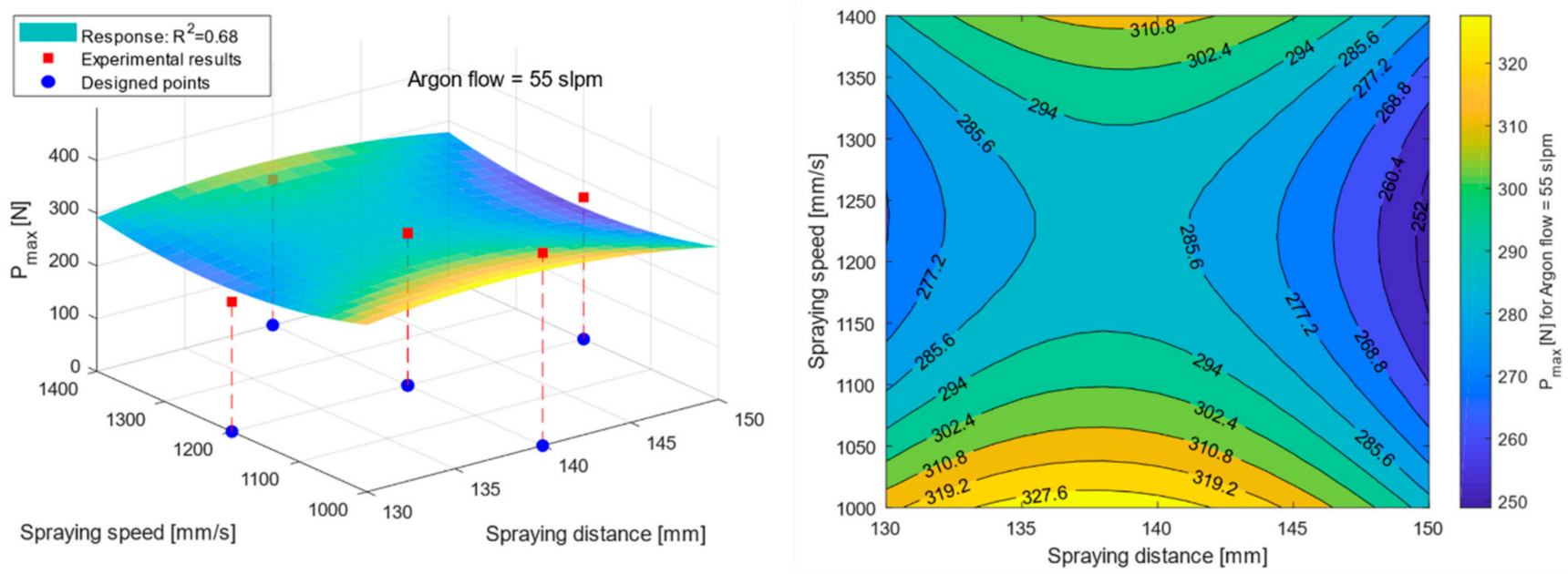

Figure 5. Response surface of the obtained $\mathrm{P}_{\max }$ for a fixed argon flow rate of 55 slpm.

\subsection{Coating Thickness}

This output variable presents the fitted response coefficients included in Table 4 . It is observed that the most significant factors that increase the thickness of the coating are the spraying distance and the argon flow rate, i.e., the gas mixture. The greater the spraying distance combined with high argon concentrations, the thicker coating is produced on the substrate. On the other hand, the variation in thickness values might be caused by a higher 
level of porosity within the coating, even if it is the adhesion is good enough; due to a great spraying distance, the particles' projection is more scattered, and spacing between deposited particles is higher, producing microvoids and, in addition, a more pronounced in-flight cooling before contacting the substrate.

Table 4. Regression coefficients for the coating thickness response considering $x_{1}, x_{2}, x_{3}$ (in codified units) and $f_{\text {out }}$ in $\mu \mathrm{m}$ and percentage over the mean thickness value.

\begin{tabular}{ccccccccccc}
\hline & $\beta_{0}$ & $\beta_{1}$ & $\beta_{2}$ & $\beta_{3}$ & $\beta_{12}$ & $\beta_{13}$ & $\beta_{23}$ & $\beta_{11}$ & $\beta_{22}$ & $\beta_{33}$ \\
\hline$(\mu \mathrm{m})$ & 178.2 & 32.5 & 25.4 & 2.6 & 11.1 & 0.9 & -0.4 & -12.0 & -38.5 & -21.5 \\
$(\%)$ & 127.0 & 23.2 & 18.1 & 1.9 & 7.9 & 0.6 & -0.3 & -8.5 & -27.4 & -15.3 \\
\hline
\end{tabular}

As shown in Figure 6, for an intermediate argon flow rate (55 slpm), the maximum coating thickness would be obtained for a process parameter combination tending to maximum spraying distances and moderate spraying speeds.
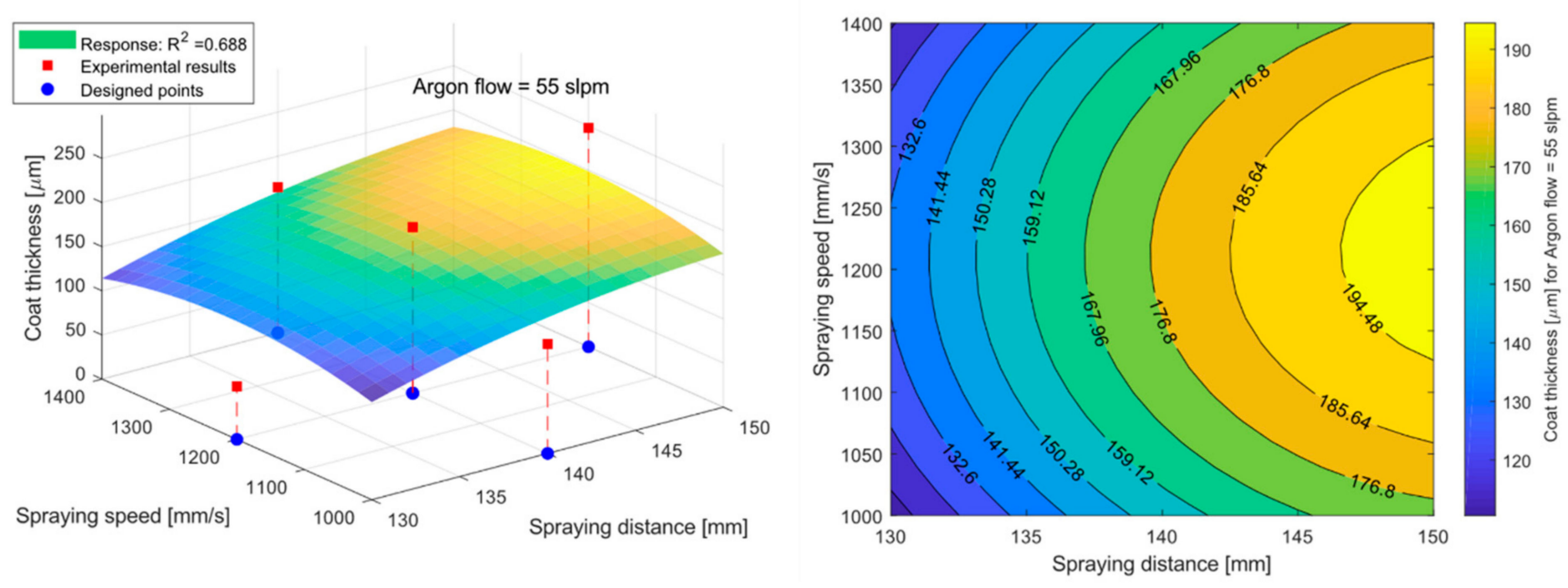

Figure 6. Response surface of the obtained coating thickness for a fixed argon flow of 55 slpm.

\subsection{Microhardness}

The response surface coefficients are shown in Table 5. It can be deduced that the highest surface hardness is reached for great spraying distances, the latter being the most significant variable. Furthermore, as shown in Figure 7, for the medium argon flow rate (55 slpm), the maximum surface microhardness is found for the corner representing the higher spraying distance and the slower spraying process.

Table 5. Regression coefficients for the hardness response considering $x_{1}, x_{2}, x_{3}$ (in codified units) and $f_{\text {out }}$ in $\mathrm{HV}$ and percentage over the mean hardness value.

\begin{tabular}{ccccccccccc}
\hline & $\boldsymbol{\beta}_{\mathbf{0}}$ & $\boldsymbol{\beta}_{\mathbf{1}}$ & $\boldsymbol{\beta}_{\mathbf{2}}$ & $\boldsymbol{\beta}_{\mathbf{3}}$ & $\boldsymbol{\beta}_{\mathbf{1 2}}$ & $\boldsymbol{\beta}_{\mathbf{1 3}}$ & $\boldsymbol{\beta}_{\mathbf{2 3}}$ & $\boldsymbol{\beta}_{\mathbf{1 1}}$ & $\boldsymbol{\beta}_{\mathbf{2 2}}$ & $\boldsymbol{\beta}_{\mathbf{3 3}}$ \\
\hline$(\mathrm{HV})$ & 148.7 & 30.5 & -22.0 & -14.3 & -35.3 & -29.3 & 26.8 & 1.4 & 15.9 & 18.4 \\
$(\%)$ & 88.8 & 18.2 & -13.1 & -8.5 & -21.0 & -17.5 & 16.0 & 0.8 & 9.5 & 11.0 \\
\hline
\end{tabular}



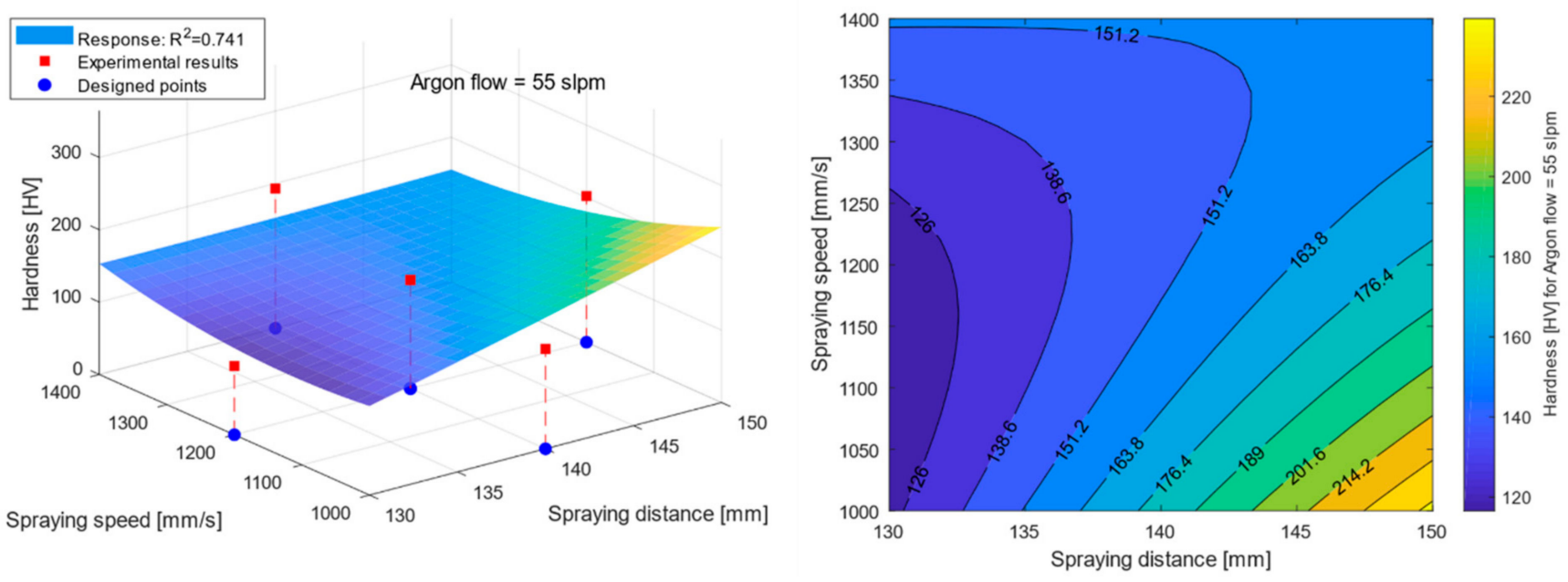

Figure 7. Response surface of the obtained hardness for a fixed argon flow rate of 55 slpm.

\subsection{Surface Roughness Ra}

According to the regression coefficients shown in Table 6, the higher values of surface roughness are produced by high argon flow rates because this is the most significant variable, as can be deduced from the $\beta_{2}$ value, and by the spraying distance, to a lesser extent.

Table 6. Regression coefficients for the $R a$ response considering $x_{1}, x_{2}, x_{3}$ (in codified units) and $f_{\text {out }}$ in $\mu \mathrm{m}$ and percentage over the mean $R a$ value.

\begin{tabular}{ccccccccccc}
\hline & $\boldsymbol{\beta}_{\mathbf{0}}$ & $\boldsymbol{\beta}_{\mathbf{1}}$ & $\boldsymbol{\beta}_{\mathbf{2}}$ & $\boldsymbol{\beta}_{\mathbf{3}}$ & $\boldsymbol{\beta}_{\mathbf{1 2}}$ & $\boldsymbol{\beta}_{\mathbf{1 3}}$ & $\boldsymbol{\beta}_{\mathbf{2 3}}$ & $\boldsymbol{\beta}_{\mathbf{1 1}}$ & $\boldsymbol{\beta}_{\mathbf{2 2}}$ & $\boldsymbol{\beta}_{\mathbf{3 3}}$ \\
\hline$(\mu \mathrm{m})$ & 9.70 & 1.17 & 1.72 & 0.14 & 0.55 & 0.79 & -0.56 & -0.81 & -0.25 & 0.42 \\
$(\%)$ & 103.6 & 12.5 & 18.4 & 1.5 & 5.8 & 8.4 & -6.0 & -8.7 & -2.6 & 4.4 \\
\hline
\end{tabular}

Additionally, as depicted in Figure 8, for a fixed distance level of $140 \mathrm{~mm}$, it is observed that the maximum surface roughness is caused by high argon flow rates, whereas the influence of the spraying speed, as can be interpreted by the contours parallel to the ordinates in the right picture of Figure 8, is very small.
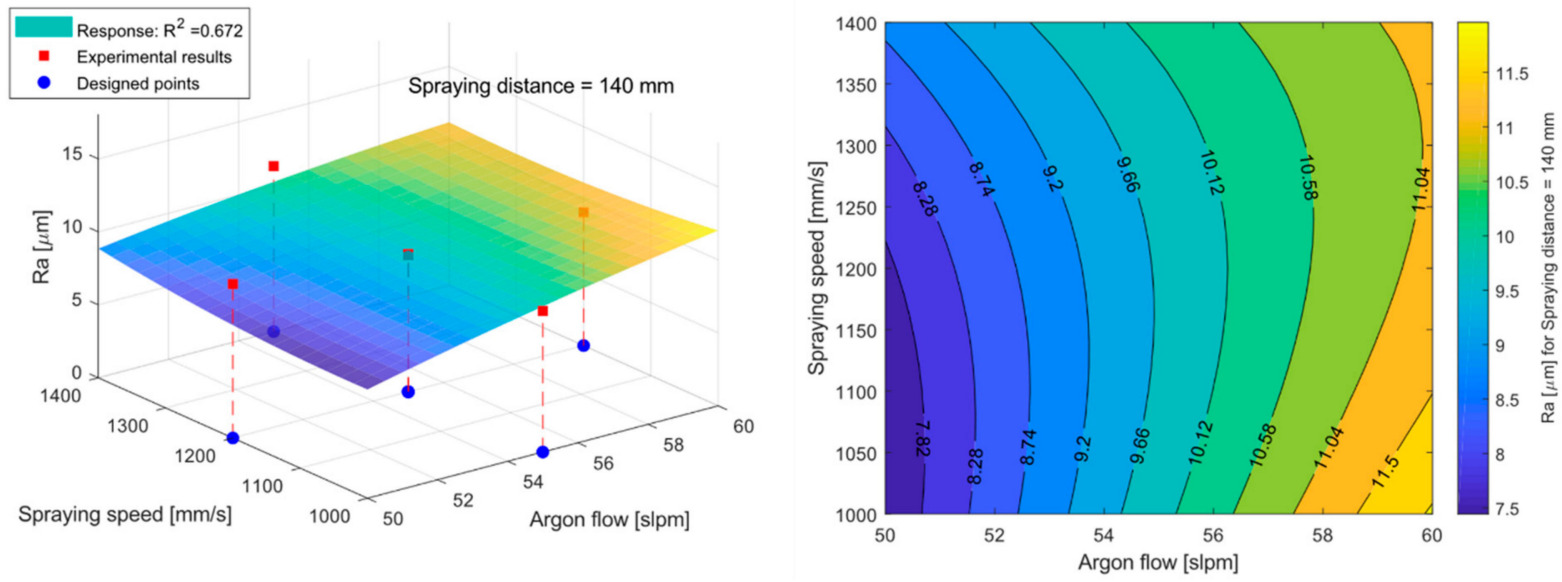

Figure 8. Response surface of the obtained $R a$ for a fixed spraying distance of $140 \mathrm{~mm}$.

In general, as mentioned above, an increase in $\mathrm{H}_{2}$ flow rate improves the heat transfer in the particles, whereas an increase in Ar stabilizes the flame, being one of the possible reasons why, in this case, the coatings are denser and more resistant for a lower argon flow rate, i.e., for a higher hydrogen content. Therefore, because the heat transfer is enhanced 
for low argon flow rates, the adherence between the coating and the substrate, and also between each layer corresponding to the 10 gun passes, is better.

\subsection{Fractographic Analysis}

Figures 9-11 show a typical example of the fracture observed for the coating-substrate system after the Small Punch testing of the specimen. In Figure 9, the complete cracking and failure patterns are observed, and two different of fracture modes can be differentiated. On one hand, a ductile breakage can be associated with the observed circumferential cracking, typical in a SPT, through the aluminum substrate whereas the coating mode of failure is brittle, as it is deduced from the star-shaped cracking pattern that is found in SPT brittle fracture [77].

In the case of Figure 10, it is possible to see in detail how the coating fails due to the bending that the substrate bears during the punching process happening in the SPT test. Specifically, the central part of the specimen coated face is subjected to tensile stresses, therefore the mode of failure that presents is more brittle when compared to the aluminum cracked substrate. However, it must be highlighted, despite the different fracture responses, that the adhesion of the coating to the substrate seems adequate.

Figure 11 shows the ductile fracture mode of the aluminum substrate demonstrated by the microvoid coalescence mechanism, in comparison to the brittle failure of the coating, as mentioned above. Thus, the micromechanisms, i.e., cleavage in Figure 10 and dimpled surfaces in Figure 11, are in accordance with the cracking patterns observed in the SPT broken specimen that shows a circumferential crack in the substrate and a star-shaped cracking process in the coating.

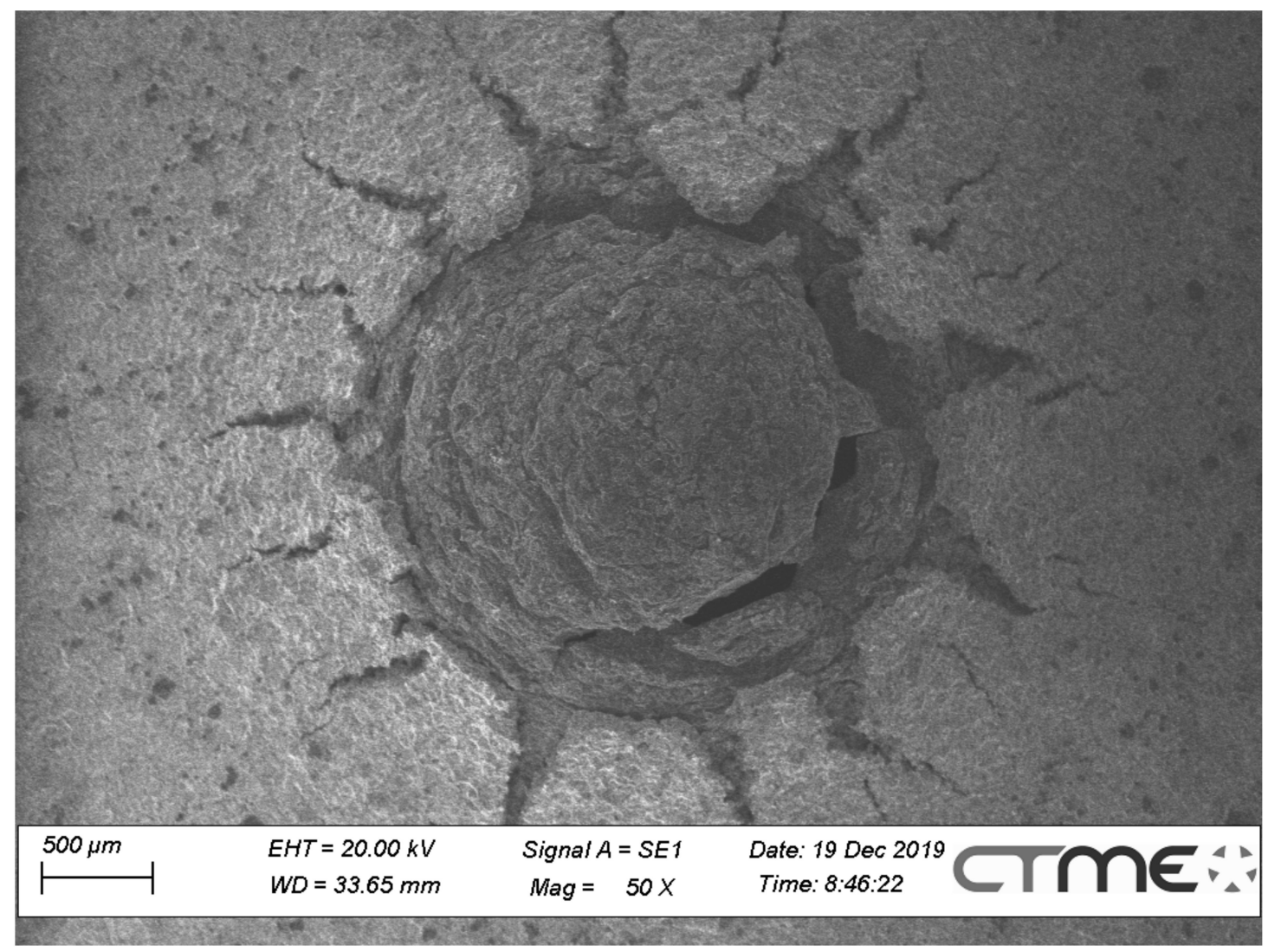

Figure 9. SEM image of the observed Small Punch Test (SPT) fracture (Test 1). 


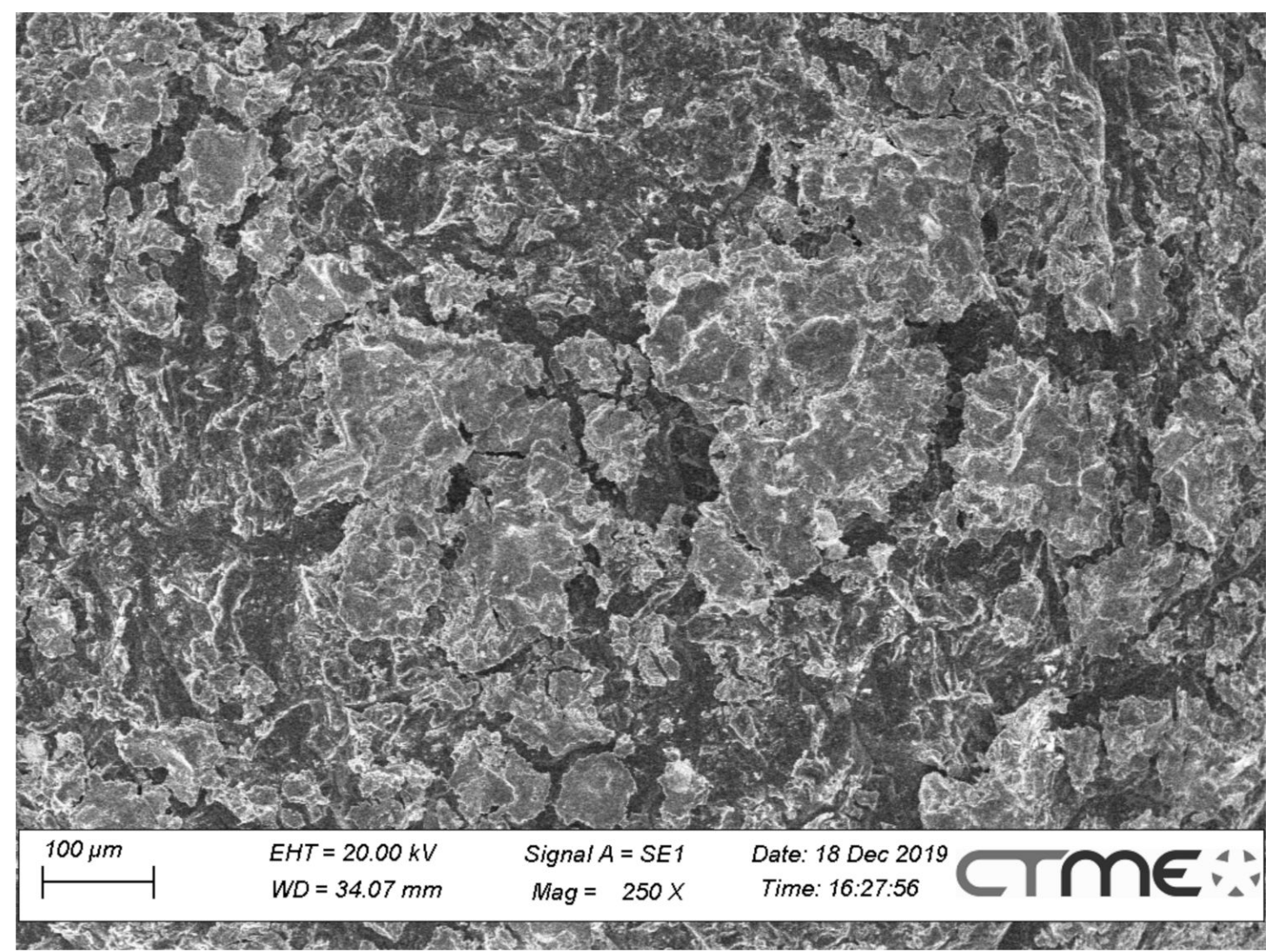

Figure 10. SEM image of the observed brittle fracture in the coating for the Small Punch test (Test 1).

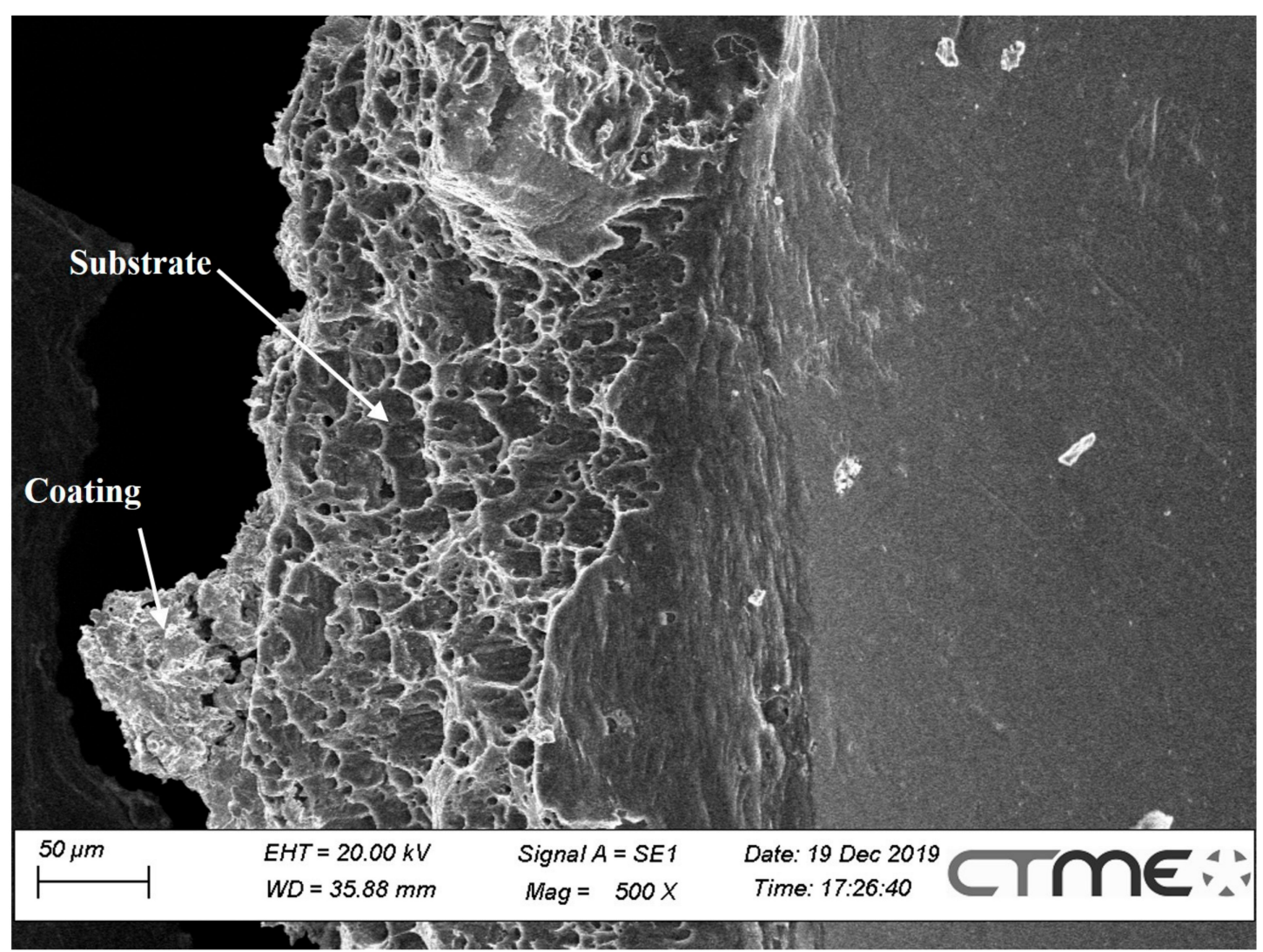

Figure 11. SEM image of the observed ductile fracture in the substrate for the Small Punch test (Test 13). 


\subsection{Coating Metallographic Analysis}

Figure 12 shows the coating obtained under the parameter combination defined for Test 2 . The defect typology associated with the coating, such as porosity and delamination, can be assessed. On the other hand, the homogeneity and the relatively uniform thickness are demonstrated, as well as the good adhesion between the substrate and coating. It should be emphasized that most defects begin after $1 / 3$ of the coating was made, i.e., on the outer layers of the coating, whereas the strip that is close to the substrate is free of porosity.

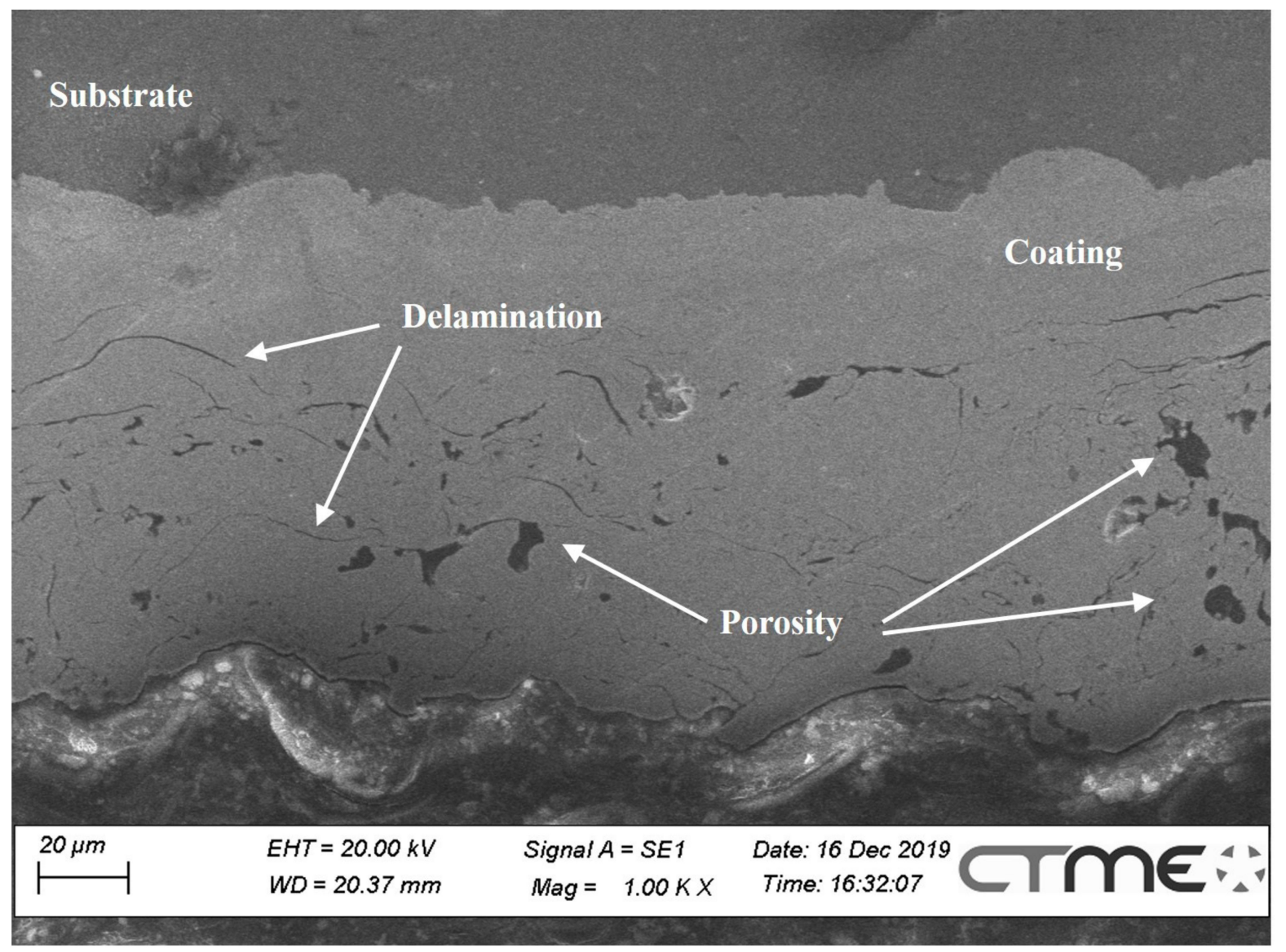

Figure 12. SEM image of the coating and the interface with the substrate for the parameter combination (Number 2).

Figure 13 shows how the adhesion between the substrate and coating is not optimal for the parameter combination, defined as Number 10; in addition, a significant increase in the number of defects is observed right from the first gun passes during spraying close to the substrate. 


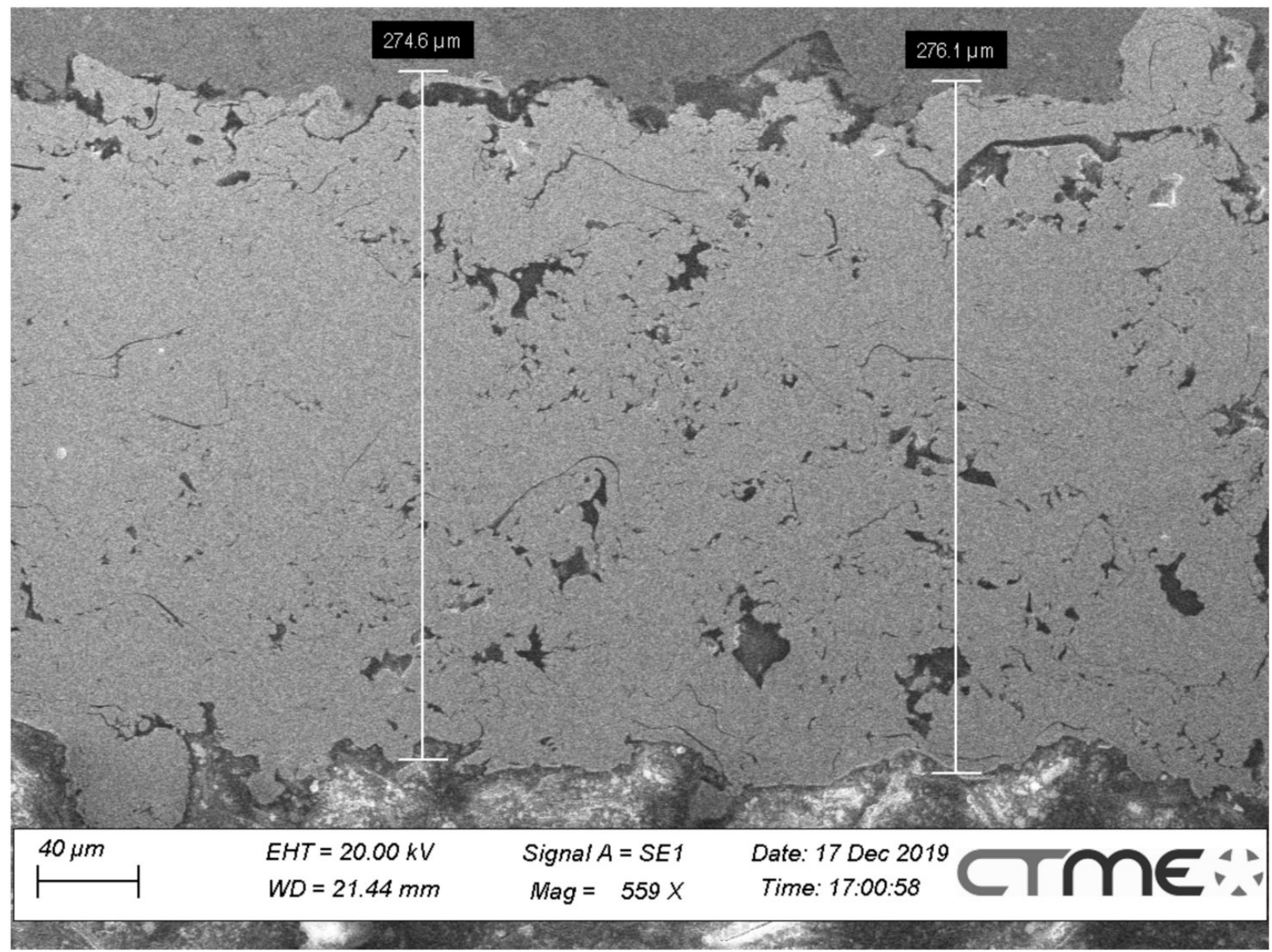

Figure 13. SEM image of the coating and the interface with the substrate for the parameter combination (Number 10). The coating thickness is also shown for two locations.

\section{Conclusions}

An experimental program was carried out with the aim of obtaining, to a first approximation, the optimal parameter combination for the coating process by means of the Atmospheric Plasma Spray technique of a Ni-Al coating on an aluminum alloy substrate. To this purpose, and within the context of mechanical characterization, the Small Punch test is proposed as an alternative to evaluating the failure mode of these coatings together with the substrate material when thin work pieces thicknesses are involved.

Results obtained through this testing methodology, analyzing the maximum load as the output response, have led to the following conclusions:

- Within the assessed range of variables, low spraying speeds and an increase in spraying distance, for intermediate values of argon flow rates, produce coatings with higher strength.

- Alternatively, the thicker coatings were obtained for a greater spraying distance combined with high argon flow rates.

- On the other hand, for a greater spraying distance and a slow spraying process, surface microhardness was maximized.

- Finally, for high argon flow rates together and great spraying distance, the highest surface roughness has been found.

It must be noted that the statistical significance has been relatively low; it is thus concluded that the studied parameter range has been too narrow in order to find high variations in mechanical properties. In future research, a broader spectrum of spraying distances and gas flow rates will be assessed. 
The fractographic and metallographic analysis have been a successful method to identify the failure mode occurring during the Small Punch test of the coating-substrate system, as well as to establish a relationship between the coating behavior and the presence of defects due to the selected parameters of APS thermal spray technique.

Author Contributions: Conceptualization, M.L.-B. and I.I.C.; methodology, M.L.-B.; software, A.D.; validation, J.M.A., D.R. and M.L.-B.; formal analysis, A.D.; investigation, A.F.; resources, A.F.; data curation, M.L.-B.; writing—original draft preparation, M.L.-B.; writing—review and editing, A.D.; visualization, M.L.-B.; supervision, J.M.A.; project administration, I.I.C.; funding acquisition, I.I.C. All authors have read and agreed to the published version of the manuscript.

Funding: The authors gratefully acknowledge financial support from the Junta of Castile and Leon by funding Recognized Research Groups through grant no. BU033G18, starting from 2018.

Data Availability Statement: Not applicable.

Conflicts of Interest: The authors declare no conflict of interest. The funders had no role in the design of the study; in the collection, analyses, or interpretation of data; in the writing of the manuscript, or in the decision to publish the results.

\section{References}

1. Legg, K.O.; Sartwell, B.D.; Legoux, J.-G.; Nestler, M.; Dambra, C.; Wang, D.; Quets, J.; Natishan, P.; Bretz, P.; Devereaux, J. Investigation of Plasma Spray Coatings as an Alternative to Hard Chrome Plating on Internal Surfaces; Report NRL/MR/6170-06-8987; Naval Research Lab: Washington, DC, USA, 2006.

2. Legg, K.O. Overview of chromium and cadmium alternative technologies. In Surface Modification Technologies XV; ASM International, Materials Park: Novelty, OH, USA; IOM Communications Ltd.: London, UK, 2002.

3. Espallargas, N.; Berget, J.; Guilemany, J.; Benedetti, A.; Suegama, P. Cr3C2-NiCr and WC-Ni thermal spray coatings as alternatives to hard chromium for erosion-corrosion resistance. Surf. Coatings Technol. 2008, 202, 1405-1417. [CrossRef]

4. United States Environmental Protection Agency (EPA US). National Emission Standards for Hazardous Air Pollutant Emissions: Hard and Decorative Chromium Electroplating and Chromium Anodizing Tanks; and Steel Pickling- $\mathrm{HCl}$ Process Facilities and Hydrochloric Acid Regeneration Plants. Dly. J. United State Gov. 2012, 77, 58219-58253.

5. Miguel, J.M.; Vizcaino, S.; Lorenzana, C.; Cinca, N.; Guilemany, J.M. Tribological Behavior of Bronze Composite Coatings Obtained by Plasma Thermal Spraying. Tribol. Lett. 2011, 42, 263-273. [CrossRef]

6. Guilemany, J.M.; Navarro, J.; Lorenzana, C.; Vizcaino, S.; Miguel, J.M. Tribological behaviour of abradable coatings obtained by atmospheric plasma spraying (APS). In Proceedings of the International Thermal Spray Conference, Singapore, 28-30 May 2001; pp. 1115-1118.

7. Carter, T.J. Common failures in gas turbine blades. Eng. Fail. Anal. 2005, 12, 237-247. [CrossRef]

8. Mazur, Z.; Luna-Ramírez, A.; Juárez-Islas, J.; Campos-Amezcua, A. Failure analysis of a gas turbine blade made of Inconel 738LC alloy. Eng. Fail. Anal. 2005, 12, 474-486. [CrossRef]

9. Tawancy, H.; Mohammad, A.; Al-Hadhrami, L.; Dafalla, H.; Alyousf, F. On the performance and failure mechanism of thermal barrier coating systems used in gas turbine blade applications: Influence of bond coat/superalloy combination. Eng. Fail. Anal. 2015, 57, 1-20. [CrossRef]

10. Kumar, S.; Kumar, M.; Handa, A. Comparative study of high temperature oxidation behavior and mechanical properties of wire arc sprayed $\mathrm{Ni} \mathrm{Cr}$ and $\mathrm{Ni} \mathrm{Al}$ coatings. Eng. Fail. Anal. 2019, 106, 104173. [CrossRef]

11. Padture, N.P.; Gell, M.; Jordan, E.H. Thermal Barrier Coatings for Gas-Turbine Engine Applications. Science 2002, 296, $280-284$. [CrossRef]

12. Bakan, E.; Vassen, R. Ceramic Top Coats of Plasma-Sprayed Thermal Barrier Coatings: Materials, Processes, and Properties. J. Therm. Spray Technol. 2017, 26, 992-1010. [CrossRef]

13. Heimann, R.B. Principles of Thermal Spraying. In Plasma-Spray Coating: Principles and Applications; Wiley: Weinheim, Germany, 1996. [CrossRef]

14. Luo, X.; Smith, G.M.; Sampath, S. On the Interplay Between Adhesion Strength and Tensile Properties of Thermal Spray Coated Laminates-Part I: High Velocity Thermal Spray Coatings. J. Therm. Spray Technol. 2018, 27, 296-307. [CrossRef]

15. Sun, J.; Chang, E.; Wu, B.; Tsai, C. The properties and performance of (ZrO2-8wt.\%Y2O3)/(chemically vapour-deposited Al2O3)/(Ni-22wt.\%Cr-10wt.\%Al-lwt.\%Y) thermal barrier coatings. Surf. Coatings Technol. 1993, 58, 93-99. [CrossRef]

16. Park, J.H.; Kim, J.S.; Lee, K.H.; Song, Y.S.; Kang, M.C. Effects of the laser treatment and thermal oxidation behavior of CoNiCrAlY/ZrO2-8wt\%Y2O3 thermal barrier coating. J. Mater. Process. Technol. 2008, 201, 331-335. [CrossRef]

17. Gray, A.; Sampson, E.R. Tech spotlight: Coating solutions for military applications. Adv. Mater. Process. 2002, 160, 41-42.

18. Oksa, M.; Turunen, E.; Suhonen, T.; Varis, T.; Hannula, S.-P. Optimization and Characterization of High Velocity Oxy-fuel Sprayed Coatings: Techniques, Materials, and Applications. Coatings 2011, 1, 17-52. [CrossRef] 
19. Gautam, R.K.S.; Rao, U.; Tyagi, R. High temperature tribological properties of Ni-based self-lubricating coatings deposited by atmospheric plasma spray. Surf. Coatings Technol. 2019, 372, 390-398. [CrossRef]

20. Anupam, A.; Kottada, R.S.; Kashyap, S.; Meghwal, A.; Murty, B.; Berndt, C.; Ang, A. Understanding the microstructural evolution of high entropy alloy coatings manufactured by atmospheric plasma spray processing. Appl. Surf. Sci. 2020, $505,144117$. [CrossRef]

21. Davis, J.R. Handbook of Thermal Spray Technology; ASM International Materials Park: Novelty, OH, USA, $2004 ;$ p. 338.

22. Ganvir, A.; Curry, N.; Govindarajan, S.; Markocsan, N. Characterization of Thermal Barrier Coatings Produced by Various Thermal Spray Techniques Using Solid Powder, Suspension, and Solution Precursor Feedstock Material. Int. J. Appl. Ceram. Technol. 2015, 13, 324-332. [CrossRef]

23. Prochazka, Z.; Khor, K.A.; Cizek, J. Influence of Input Parameters on Splat Formation and Coating Thermal Diffusivity in Plasma Spraying. Adv. Eng. Mater. 2006, 8, 645-650. [CrossRef]

24. Nouri, A.; Sola, A. Powder morphology in thermal spraying. J. Adv. Manuf. Process. 2019, 1, 10020. [CrossRef]

25. Janisson, S.; Vardelle, A.; Coudert, J.F.; Meillot, E.; Pateyron, B.; Fauchais, P. Plasma Spraying Using Ar-He-H2 Gas Mixtures. J. Therm. Spray Technol. 1999, 8, 545-552. [CrossRef]

26. Chen, X.; Kuroda, S.; Ohnuki, T.; Araki, H.; Watanabe, M.; Sakka, Y. Effects of Processing Parameters on the Deposition of Yttria Partially Stabilized Zirconia Coating During Suspension Plasma Spray. J. Am. Ceram. Soc. 2016, 99, 3546-3555. [CrossRef]

27. Fauchais, P.; Vardelle, A.; Dussoubs, B. Quo Vadis Thermal Spraying? J. Therm. Spray Technol. 2001, 10, 44-66. [CrossRef]

28. Fauchais, P. Understanding plasma spraying. J. Phys. D Appl. Phys. 2004, 37, R86-R108. [CrossRef]

29. $\mathrm{Ng}, \mathrm{H}$.; Gan, Z. A finite element analysis technique for predicting as-sprayed residual stresses generated by the plasma spray coating process. Finite Elements Anal. Des. 2005, 41, 1235-1254. [CrossRef]

30. Teixeira, V.; Andritschky, M.; Fischer, W.; Buchkremer, H.; Stöver, D. Analysis of residual stresses in thermal barrier coatings. J. Mater. Process. Technol. 1999, 92-93, 209-216. [CrossRef]

31. Sarikaya, O. Effect of the substrate temperature on properties of plasma sprayed Al2O3 coatings. Mater. Des. 2005, 26, 53-57. [CrossRef]

32. Fogarassy, P.; Turquier, F.; Lodini, A. Residual stress in plasma sprayed zirconia on cylindrical components. Mech. Mater. 2003, 35, 633-640. [CrossRef]

33. Mellali, M.; Fauchais, P.; Grimaud, A. Influence of substrate roughness and temperature on the adhesion/cohesion of alumina coatings. Surf. Coatings Technol. 1996, 81, 275-286. [CrossRef]

34. Guessasma, S.; Bounazef, M. Experimental Design to Study the Effect of APS Process Parameters on Friction Behaviour of Alumina-Titania Coatings. Adv. Eng. Mater. 2004, 6, 907-910. [CrossRef]

35. Helminiak, M.A.; Yanar, N.M.; Pettit, F.S.; Taylor, T.A.; Meier, G.H. Factors affecting the microstructural stability and durability of thermal barrier coatings fabricated by air plasma spraying. Mater. Corros. 2012, 63, 929-939. [CrossRef]

36. Prashar, G.; Vasudev, H.; Thakur, L. Performance of different coating materials against slurry erosion failure in hydrodynamic turbines: A review. Eng. Fail. Anal. 2020, 115, 104622. [CrossRef]

37. Song, Y.; Zhuan, X.; Wang, T.; Chen, X. Evolution of thermal stress in a coating/substrate system during the cooling process of fabrication. Mech. Mater. 2014, 74, 26-40. [CrossRef]

38. Krella, A.; Sobczyk, A.; Krupa, A.; Jaworek, A. Thermal resistance of Al2O3 coating produced by electrostatic spray deposition method. Mech. Mater. 2016, 98, 120-133. [CrossRef]

39. Premkumar, K.; Balasubramanian, K. Evaluation of cyclic oxidation behavior and mechanical properties of nanocrystalline composite HVOF coatings on SA 210 grade C material. Eng. Fail. Anal. 2019, 97, 635-644. [CrossRef]

40. Choi, B.-Y.; Liang, J.; Gao, W. Correlation of microstructure and high temperature oxidation resistance of plasma sprayed NiCrAl, NiCrAlY, and TiAlO composite coatings on Ti-6Al-4V. Met. Mater. Int. 2005, 11, 499-503. [CrossRef]

41. Ahmed, R.; Hadfield, M. Mechanisms of Fatigue Failure in Thermal Spray Coatings. J. Therm. Spray Technol. 2002, 11, 333-349. [CrossRef]

42. Karaoglanli, A.C.; Dikici, H.; Kucuk, Y. Effects of heat treatment on adhesion strength of thermal barrier coating systems. Eng. Fail. Anal. 2013, 32, 16-22. [CrossRef]

43. Boruah, D.; Robinson, B.; London, T.; Wu, H.; De Villiers-Lovelock, H.; McNutt, P.; Doré, M.; Zhang, X. Experimental evaluation of interfacial adhesion strength of cold sprayed Ti-6Al-4V thick coatings using an adhesive-free test method. Surf. Coatings Technol. 2020, 381, 125130. [CrossRef]

44. Kang, J.-J.; Xu, B.-S.; Wang, H.-D.; Wang, C.-B.; Zhu, L.-N. Delamination failure monitoring of plasma sprayed composite ceramic coatings in rolling contact by acoustic emission. Eng. Fail. Anal. 2018, 86, 131-141. [CrossRef]

45. International Organization for Standardization. Thermal Spraying-Determination of Tensile Adhesive Strength (ISO 14916:2017). 2017. Available online: https:/ / www.iso.org/standard/60995.html (accessed on 2 February 2021).

46. International Organization for Standardization. Thermal Spraying-Evaluation of Adhesion/Cohesion of Thermal Sprayed Ceramic Coatings by Transverse Scratch Testing (ISO 27307:2015). 2015. Available online: https://www.iso.org/standard/51692. html (accessed on 2 February 2021).

47. International Organization for Standardization. Thermal Spraying-Classification Method of Adhesive Strength by Indentation (ISO 19207:2016.). 2016. Available online: https://www.iso.org/standard/63998.html (accessed on 2 February 2021). 
48. ASTM C633-13 (2017), Standard Test Method for Adhesion or Cohesion Strength of Thermal Spray Coatings; ASTM International: West Conshohocken, PA, USA, 2017; Available online: www.astm.org (accessed on 18 March 2021).

49. Hivart, P.; Crampon, J. Interfacial indentation test and adhesive fracture characteristics of plasma sprayed cermet $\mathrm{Cr} 3 \mathrm{C} 2 / \mathrm{Ni}-\mathrm{Cr}$ coatings. Mech. Mater. 2007, 39, 998-1005. [CrossRef]

50. Azarmi, F.; Sevostianov, I. Comparative micromechanical analysis of alloy 625 coatings deposited by air plasma spraying, wire arc spraying, and cold spraying technologies. Mech. Mater. 2020, 144, 103345. [CrossRef]

51. Dwivedi, G.; Viswanathan, V.; Sampath, S.; Shyam, A.; Lara-Curzio, E. Fracture Toughness of Plasma-Sprayed Thermal Barrier Ceramics: Influence of Processing, Microstructure, and Thermal Aging. J. Am. Ceram. Soc. 2014, 97, 2736-2744. [CrossRef]

52. He, X.; Song, P.; Yu, X.; Li, C.; Huang, T.; Zhou, Y.; Li, Q.; Lü, K.; Lü, J.; Lu, J. Evolution of cracks within an Al2O3-40 wt\%TiO2/NiCoCrAl gradient coating. Ceram. Int. 2018, 44, 20798-20807. [CrossRef]

53. Nordhorn, C.; Mücke, R.; Mack, D.E.; Vaßen, R. Probabilistic lifetime model for atmospherically plasma sprayed thermal barrier coating systems. Mech. Mater. 2016, 93, 199-208. [CrossRef]

54. Kind, N.; Berthel, B.; Fouvry, S.; Poupon, C.; Jaubert, O. Plasma-sprayed coatings: Identification of plastic properties using macro-indentation and an inverse Levenberg-Marquardt method. Mech. Mater. 2016, 98, 22-35. [CrossRef]

55. Rezaei, S.; Arghavani, M.; Wulfinghoff, S.; Kruppe, N.C.; Brögelmann, T.; Reese, S.; Bobzin, K. A novel approach for the prediction of deformation and fracture in hard coatings: Comparison of numerical modeling and nanoindentation tests. Mech. Mater. 2018, 117, 192-201. [CrossRef]

56. Lewis, F.; Mantovani, D. Methods to Investigate the Adhesion of Soft Nano-Coatings on Metal Substrates-Application to Polymer-Coated Stents. Macromol. Mater. Eng. 2008, 294, 11-19. [CrossRef]

57. Chen, H.; Rushworth, A.; Sun, W.; He, J.; Guo, H. Some considerations in using the small punch testing for thermally sprayed CoNiCrAlY coatings. Surf. Coatings Technol. 2019, 357, 684-690. [CrossRef]

58. Chen, H.; Hyde, T.; Voisey, K.; McCartney, D.; Mc Cartney, G. Application of small punch creep testing to a thermally sprayed CoNiCrAlY bond coat. Mater. Sci. Eng. A 2013, 585, 205-213. [CrossRef]

59. Jackson, G.; Sun, W.; McCartney, D.G. The Application of the Small Punch Tensile Test to Evaluate the Ductile to Brittle Transition of a Thermally Sprayed CoNiCrAlY Coating. Key Eng. Mater. 2017, 734, 144-155. [CrossRef]

60. Saunders, S.R.J.; Banks, J.P.; Wright, M. Measurement of Ductile Brittle Transition Temperature of Coatings Using the Small Punch Test; Report NPL MATC(A)60; National Physical Laboratory: Teddington, Middlesex, UK, 2001.

61. Nambu, T.; Shimizu, K.; Matsumoto, Y.; Rong, R.; Watanabe, N.; Yukawa, H.; Morinaga, M.; Yasuda, I. Enhanced hydrogen embrittlement of Pd-coated niobium metal membrane detected by in situ small punch test under hydrogen permeation. J. Alloy. Compd. 2007, 446-447, 588-592. [CrossRef]

62. Kameda, J.; Bloomer, T.; Sugita, Y.; Ito, A.; Sakurai, S. Mechanical properties of aluminized CoCrAlY coatings in advanced gas turbine blades. Mater. Sci. Eng. A 1997, 234-236, 489-492. [CrossRef]

63. Kameda, J.; Bloomer, T.E.; Sakurai, S. Oxidation/Carbonization/Nitridation and In-Service Mechanical Property Degradation of CoCrAlY Coatings in Land-Based Gas Turbine Blades. J. Therm. Spray Technol. 1999, 8, 440-446. [CrossRef]

64. Gallino, E.; Massey, S.; Tatoulian, M.; Mantovani, D. Plasma polymerized allylamine films deposited on 316L stainless steel for cardiovascular stent coatings. Surf. Coat. Technol. 2010, 205, 2461-2468. [CrossRef]

65. Eskner, M. Mechanical Behaviour of Gas Turbine Coatings. Ph.D. Thesis, Department of Materials Science and Engineering Royal Institute of Technology, Stockholm, Sweden, 3 June 2004. Available online: http:/ / kth.diva-portal.org/smash/get/diva2: 9627/FULLTEXT01.pdf (accessed on 4 February 2021).

66. Latreche, H.; Doublet, S.; Tegeder, G.; Wolf, G.; Masset, P.; Weber, T.; Schütze, M. Behaviour of NiAl APS-coatings in chlorinecontaining atmospheres. Mater. Corros. 2008, 59, 573-583. [CrossRef]

67. Abu-Warda, N.; López, A.; López, M.; Utrilla, M. High temperature corrosion and wear behavior of HVOF-sprayed coating of Al2O3-NiAl on AISI 304 stainless steel. Surf. Coatings Technol. 2019, 359, 35-46. [CrossRef]

68. Metallic Materials-Small Punch Test Method; prEN 10371; European Committee for Standardization (CEN): Brussels, Belgium, 2019.

69. Ju, J.-B.; Kwon, D. Assessment of fracture characteristics from revised small punch test using pre-cracked specimen. Met. Mater. 1998, 4, 742-746. [CrossRef]

70. Arunkumar, S. Overview of Small Punch Test. Met. Mater. Int. 2019, 26, 719-738. [CrossRef]

71. International Organization for Standardization. (1997)-Geometrical Product Specifications (GPS)—Surface texture: Profile method — Terms, definitions and surface texture parameters (ISO 4287:1997). Available online: https://www.iso.org/standard/10132.html (accessed on 2 February 2021).

72. Azarmi, F.; Coyle, T.; Mostaghimi, J. Optimization of Atmospheric Plasma Spray Process Parameters using a Design of Experiment for Alloy 625 coatings. J. Therm. Spray Technol. 2008, 17, 144-155. [CrossRef]

73. Mawdsley, J.R.; Su, Y.; Faber, K.; Bernecki, T.F. Optimization of small-particle plasma-sprayed alumina coatings using designed experiments. Mater. Sci. Eng. A 2001, 308, 189-199. [CrossRef]

74. Ramachandran, C.S.; Balasubramanian, V.; Ananthapadmanabhan, P.V. Multiobjective Optimization of Atmospheric Plasma Spray Process Parameters to Deposit Yttria-Stabilized Zirconia Coatings Using Response Surface Methodology. J. Therm. Spray Technol. 2010, 20, 590-607. [CrossRef]

75. Kanta, A.F.; Montavon, G.; Coddet, C. Predicting Spray Processing Parameters from Required Coating Structural Attributes by Artificial Intelligence. Adv. Eng. Mater. 2006, 8, 628-635. [CrossRef] 
76. Kanta, A.-F.; Montavon, G.; Planche, M.-P.; Coddet, C. Artificial neural networks implementation in plasma spray process: Prediction of power parameters and in-flight particle characteristics vs. desired coating structural attributes. Surf. Coatings Technol. 2009, 203, 3361-3369. [CrossRef]

77. Turba, K.; Hurst, R.; Hähner, P. Evaluation of the ductile-brittle transition temperature in the NESC-I material using small punch testing. Int. J. Press. Vessel. Pip. 2013, 111-112, 155-161. [CrossRef] 